Kari Sormunen, $\mathrm{PhD}$, is the senior lecturer of science education in the Department of Applied Education at the University of Joensuu. Nowadays he is also the head of department. He is particularly interested in focusing his research on the epistemological beliefs held by secondary school students and student teachers, Nature of Science studies, and student teachers' pedagogical content knowledge.

\title{
From Epistemological Constrains towards Epistemological Resources in the Science Classroom
}

\begin{abstract}
This paper relates to the research of personal epistemology. Two different models are presented which originate from the areas of research on the developmental levels of epistemological beliefs and the epistemological resources. In addition the concept of pupils' 'epistemic views' is defined for the purpose in this particular study. The empirical aim of this study was to discover how pupils assessed their own knowledge, their physics teacher's knowledge and also that of scientists. The context of the study was 12 hours of science lessons, during which eighteen $7^{\text {th }}$-grade pupils were taught the modelling idea connected to the topic 'structure of matter. The core data in this qualitative case study was based on post-interviews. The pupils' views could be classified into all developmental levels of epistemological views. Some of the pupils even possessed beliefs suitable to all levels; this sample challenges the developmental nature of the beliefs. The pupils' epistemic views were compatible with the epistemological resources model, but also new resources were discovered. It seems that in the science classroom the pupils' views should be regarded as epistemological resources instead of treating them as epistemological constrains.
\end{abstract}

\section{STUDYING PERSONAL EPISTEMOLOGICAL VIEWS OF PUPILS}

The aim of this study was to explore $7^{\text {th }}$-graders' views on knowledge and their acquisition of knowledge in the context of science education at the comprehensive school level. The pupils' views were examined in the context of a teaching sequence of 12 hours, in which their study focused on the structure and states of matter (see Sormunen, 2004). Studying pupils' epistemic views in the context of the pedagogics of science is related, in theoretical terms, both to epistemological beliefs and to conceptions related to Nature of Science (NoS). The first involves epistemological psychology, in which an individual's epistemological beliefs are studied from the perspective of cognitive psychology. This is an approach that was initiated by Jean Piaget's genetic epistemology. It was then further developed by William Perry in the 1970s, and since then this research approach has been conducted with an emphasis on developmental issues. (Hofer \& Pintrich, 1997.)

Nature of Science (NoS) research has concentrated on students', teachers' and scientists' notions of science (see Lederman, 1992, p. 332); the focus in this study concentrates on pupils' views about scientific enterprise and scientific knowledge. NoS combines the history, philosophy, psychology 
and sociology of science (see, e.g., McComas \& Olson, 1998). In the following, the bias is on the personal epistemology research, because the goal of this article is to raise the question, whether the developmental framework of personal epistemology is the only appropriate insight when $7^{\text {th }}$. grade pupils' epistemological views are studied.

\section{Research field on personal epistemology}

There has been a growing need both for psychologists and educators to discover features describing personal epistemological development and epistemological beliefs. Piaget used the term 'genetic epistemology' to describe his theory of intellectual development, initiating the interest of developmental psychologists in this intersection of philosophy and psychology. Having a basis in the Piagetian framework, Perry (1970) attempted to understand how students interpreted pluralistic educational experiences. Following Perry's schema, most researchers in the field have posed models that are to some degree structural, developmental sequences (see Hofer \& Pintrich, 1997, for a review).

Alternatively, it has been argued that individuals may develop different epistemological stances in different domains and that some aspects, of some of these stances, are domain-specific (Smith, Maclin, Houghton \& Hennessey, 2000; Hofer \& Pintrich, 1997). This might have been the reason why there has also been interest in the topic in the fields of science and mathematics education. The bias towards personal epistemology in educational settings has mostly been either in general beliefs or in more contextual views.

In the field of science education, many of the epistemological studies are related to the nature of science research (see e.g., Lederman, 1992; Kelly, Chen \& Crawford, 1998, Abd-El-Khalick \& Lederman, 2000, for reviews) and they themselves are not usually so committed to developmental epistemology. The research on young persons' epistemological commitments or beliefs has, however, mainly concentrated on the general and formal ideas of philosophy (see Figure 1). Young

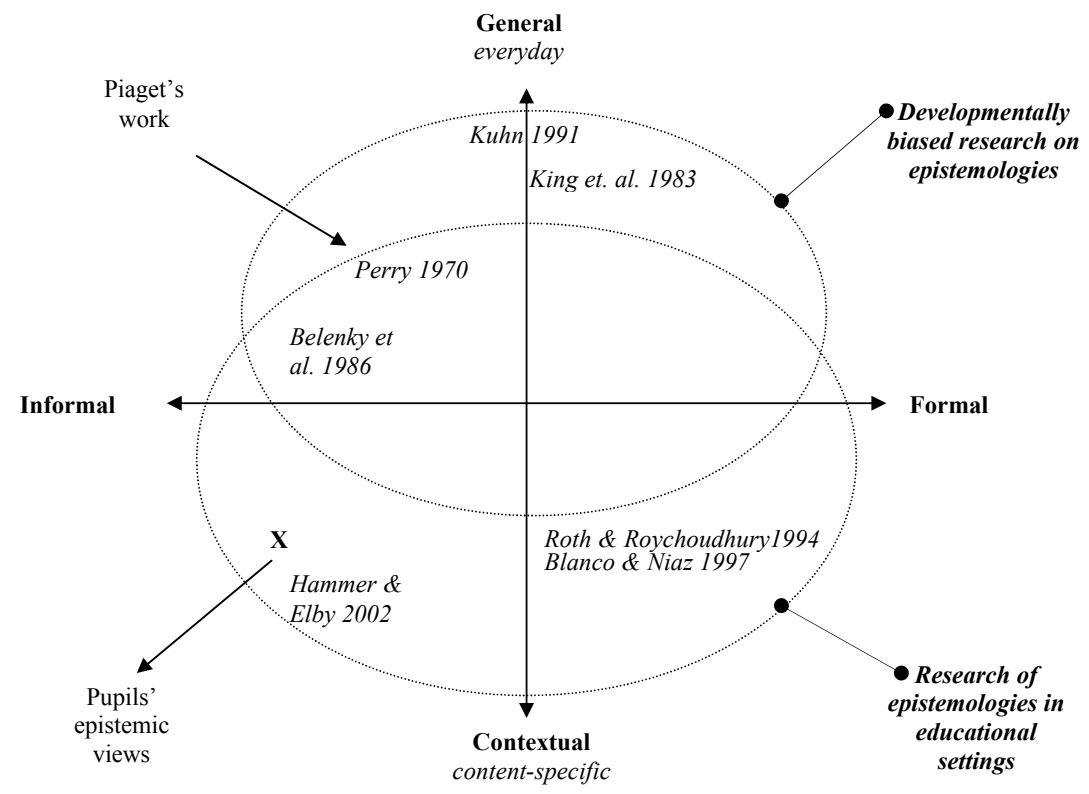

Figure 1. Different research frameworks with exemplary studies on personal epistemologies 
people's views and beliefs have been compared to various philosophical trends like "objectivist" or "constructivist-relativist position" (Roth \& Roychoudhury, 1994), or "positivist" or "lakatosian" perspectives (Blanco \& Niaz, 1997): the target has been in categorising young people's views and beliefs according to the existing ideas of scientists or other "adults".

In the following, two frameworks of epistemological beliefs are described: a general model considering the developmental levels of epistemological beliefs and a model of epistemological resources. The former is a synthesis of a number of studies with developmental insight into personal thinking on the general level (see Hofer \& Pintrich, 1997 for a review), and the second is more context-bound without general and developmental aspects (Hammer \& Elby, 2002). These models are taken into account when examining the findings concerning 7th-graders' epistemological beliefs.

\section{General model describing the development of epistemological thinking}

In almost all of the developmental approaches (see Figure 1), it has been argued that at best, students start out with a limited, fact-based epistemology for thinking about knowledge in their everyday life. After two or three phases the individual's beliefs might develop towards more relativistic thinking. In the following, a synthesis of the studies that depict epistemological development through various steps or stances, is summarised as a four-level model (see Table 1). The analysis is based on the studies of Perry (1970), Belenky, Clinchy, Goldberger and Tarule (1986), BaxterMagolda (1992), King, Kitchener, Davison, Parker and Wood (1983), and Kuhn (1991), and it has been reviewed according to the viewpoints made by Hofer and Pintrich (1997) and Boyes and Chandler (1992); see it in detail in Sormunen (2004, pp. 229-237).

On the lowest level knowledge is considered to be absolute and objective: it exists outside of individuals. It is also simple and certain of its nature. The beliefs belonging to this level are also dualistic: things are right or wrong, good or bad. Authorities know the truth and they transmit the knowledge. On the second level, multiple views about knowledge are perceived: people have different conceptions of things, and individuals' personal subjectivity emerges. Multiplicity is considered to be a continuum after absolutism, and individuals also notice the possible inaccuracy of knowledge. 'Truth' still exists, but it might not be known at the moment. The absolute position of authorities is questioned and uncertainty arises; their knowledge is criticised, and disagreements between authorities are seen arising from their inability to find the right answers.

Table 1. Levels of epistemological beliefs

\begin{tabular}{|c|c|c|c|}
\hline Level & $\begin{array}{l}\text { Nature of } \\
\text { knowledge }\end{array}$ & Features of knowledge & Role of authority \\
\hline 1 & $\begin{array}{l}\text { Knowledge is } \\
\text { "absolute" }\end{array}$ & $\begin{array}{l}\text { Objectivity, certainty, and } \\
\text { simplicity of knowledge }\end{array}$ & $\begin{array}{l}\text { Authorities have absolute } \\
\text { positions; they are listened } \\
\text { to and referred to }\end{array}$ \\
\hline II & $\begin{array}{l}\text { "Multiplicity" of } \\
\text { knowledge }\end{array}$ & $\begin{array}{l}\text { Subjectivity and } \\
\text { uncertainty of knowledge } \\
\text { is recognised; multiplicity } \\
\text { of views }\end{array}$ & $\begin{array}{l}\text { Authorities may have the } \\
\text { right answers; they do not } \\
\text { know everything }\end{array}$ \\
\hline III & $\begin{array}{l}\text { "Relativity" of } \\
\text { knowledge }\end{array}$ & $\begin{array}{l}\text { Meanings are constructed } \\
\text { by individuals; knowledge } \\
\text { is questioned; doubting }\end{array}$ & $\begin{array}{l}\text { Authorities are strongly } \\
\text { questioned }\end{array}$ \\
\hline IV & $\begin{array}{l}\text { Knowledge is } \\
\text { "contextual" }\end{array}$ & $\begin{array}{l}\text { Knowledge is constructed; } \\
\text { concluding is emphasised }\end{array}$ & $\begin{array}{l}\text { Authorities are critically } \\
\text { evaluated }\end{array}$ \\
\hline
\end{tabular}


Transition from the previous lower levels to the third level means quite a radical change in individuals' epistemological thinking: one moves from dualistic right/wrong or either/or thinking towards personal meaning making. Individuals become independent knowers and they start their own processes of analysing and concluding. This stage is featured through the relativity of knowledge. When one comes to understand the human origin of knowledge and the relativistic nature of it, as a sequence all knowledge might be doubted, which may even lead to dogmatism or skeptism. In any case, on this third level authorities are strongly questioned. On the highest epistemological level, the relativistic conceptions of knowledge have changed in such a way that the individual sees knowledge and truth contextually. Knowledge is seen as being constructed and the knower is tightly connected to the knowledge; an individual sees himself as a part of constructing process. A person is able to generalise his/her views and consider knowledge according to contexts; personal conclusions are emphasised. Authorities are critically evaluated; their knowledge might not be certain, but it is usually accepted as being more reliable than one's own knowledge.

\section{Model of epistemological resources}

Hammer and Elby (2002) have suggested a novel, alternative framework for detecting and interpreting learners' epistemologies. They "seek a framework of epistemological resources, smaller and more general than theories or traits that can accommodate contextual dependence and provide an account of productive resources" (p. 176). The resources here (see Table 2) refer to cognitive resources from which learners may construct more adequate understanding.

Table 2. Epistemological resources (after Hammer \& Elby 2002, pp. 177-181)

\begin{tabular}{|l|l|}
\hline $\begin{array}{l}\text { Categories of epistemological } \\
\text { resources }\end{array}$ & Examples of resources \\
\hline $\begin{array}{l}\text { Resources for understanding the } \\
\text { nature and sources of knowledge }\end{array}$ & $\begin{array}{l}\text { knowledge as propagated stuff } \\
\text { knowledge as free creation } \\
\text { knowledge as fabricated stuff } \\
\text { knowledge as direct perception } \\
\text { knowledge as inherent }\end{array}$ \\
\hline $\begin{array}{l}\text { Resources for understanding } \\
\text { epistemological activities }\end{array}$ & $\begin{array}{l}\text { accumulation } \\
\text { formation } \\
\text { checking } \\
\text { application } \\
\text { comparing, sorting } \\
\text { naming, counting }\end{array}$ \\
\hline $\begin{array}{l}\text { Resources for understanding } \\
\text { epistemological forms }\end{array}$ & $\begin{array}{l}\text { stories } \\
\text { rules } \\
\text { rule system } \\
\text { facts } \\
\text { lists, categories } \\
\text { words, numbers }\end{array}$ \\
\hline $\begin{array}{l}\text { Resources for understanding } \\
\text { epistemological stances }\end{array}$ & $\begin{array}{l}\text { belief / disbelief } \\
\text { doubting } \\
\text { understanding / puzzlement } \\
\text { acceptance }\end{array}$ \\
\hline
\end{tabular}


The first category of resources is for understanding the general nature of knowledge (propagation, creation, fabrication, etc.) and how it originates. The second and third categories are resources for understanding epistemological activities (accumulation, formation, checking, application, etc.) and forms (stories, rules, rule system, facts, lists, etc.), which follow the notions of "epistemic games" and "epistemic forms", as developed by Collins and Ferguson (1993). In the fourth category there are resources for understanding stances one may take towards knowledge (belief / disbelief, doubt, understanding / puzzlement, acceptance, etc.). The viewpoint of Hammer and Elby has contextual and informal features of epistemological research: the epistemological resources arise in the particular context and they are not compared against well-defined ideas in formal epistemology (see Figure 1).

\section{PUPILS' “ePISTEMIC VIEWS' FEATURED IN THIS STUdY}

It is assumed in this study, that a contextual and informal approach has some advantages, particularly in opening new insights for evaluating young pupils' epistemological thoughts and the ideas behind them. The framework of this study is not developmental, and the emphasis is on the context from which the pupils' ideas arise (cf. Figure 1). Pupils' personal epistemologies may not be consistent, or expressed in the terms a philosopher would use; consequently the concept, pupils' 'epistemic views', is used instead of epistemological beliefs. The word 'epistemic' has fewer connotations of a worked-out intellectual position than 'epistemological' views (cf. Donnelly, 1999). The reason for using quite a neutral concept, 'view' instead of 'belief', originates from the notions that 'beliefs' might be treated as 'personal theories'. However, the standpoints of this study do not meet all the prerequisites for considering beliefs as theories (see Sormunen, 2004, pp. 87-88; cf. Hofer \& Pintrich, 1997, pp. 117-118). When compared to the different research frameworks presented in Figure 1, this study on pupils' epistemic views can be considered as context-dependent and informal in nature.

\section{Context}

The context of this study consisted of a teaching intervention for $7^{\text {th }}$-grade physics. It is described in more detail in Saari \& Viiri (2003). The target group consisted of eighteen pupils: ten girls and eight boys, who were 13 years of age (the codes attached to the pupils in the main study were P21-P38, see the citations in the chapter Results). The aim of the intervention was to teach the pupils the general ideas of modelling, by teaching them how to use models in learning the states of matter (gas, liquid, solid). So called curricular models, i.e. particle model and continuous model, were utilized to portray the most important aspects of matter to the pupils. The intention was for pupils to develop their general idea of modelling through these "concrete" examples of modelling aided by the teacher's general comments about modelling in connection with these models. Whenever possible, the models were tested experimentally. The aim was to explain to the pupils the process of constructing a scientific model: also to introduce the methods, representations, concepts, and reasons which scientists use when they construct models. The purpose of the teaching was to influence the pupils' ideas of modelling. The duration of the teaching sequence was 12 hours and it had features of social constructivist pedagogy (cf. Smith et al., 2000) in which pupils actively developed, tested and revised their ideas in collaboration with their peers and their teacher.

\section{Research questions}

The research task of this study was to discover, what the pupils' conceptions of knowledge and knowing, i.e. their epistemic views, are in the context of the modelling of the states of matter. First, their views were approached from three different perspectives: their own, their teacher's and a scientist's:

1. How do pupils describe the judgement and the certainty of their own knowledge, that of their teacher, and scientists' knowledge?

The first research question was developed from the two dimensions suggested, being among the main features of epistemological views: the judgement of knowledge and the certainty of knowledge 
(Hofer \& Pintrich, 1997). The questions also combine so-called proximal and distal knowledge of the nature of science (cf. Hogan, 2000), because they deal both with the pupils' views about their own knowledge (proximal) and with their views about professional science (distal) enterprise (scientists' knowledge).

Furthermore, the qualitative contents of the pupils' epistemic views in this case study, are examined in the light of two models of epistemological beliefs, i.e. the levels of epistemological beliefs and the perspective of epistemological resources:

2. What kind of connections are there in the pupils' epistemic views in regard to the levels of epistemological beliefs or the model of epistemological resources?

The intention is not to compare these models to each other, but to get new insights when studying personal epistemologies in the school science context.

\section{Method}

The present study is by nature an exploratory case study; this strategic choice fits in studying phenomena that are tightly connected to its context (Yin 1994; Hitchcock \& Hughes 1995). The main feature of the former studies of personal epistemologies has been a quantitative methodological approach, common to the majority of cognitive psychological studies. In the present study, however, a qualitative approach based on phenomenography was deliberately chosen, because it admits that people's conceptions and views can vary from one situation or context to another forming variation sources (Säljö, 1988) or variation spaces (Carlsson 1999). Due to facing different methodological challenges, a pilot phase was first applied so that the process of data-gathering could be tested and developed (see Sormunen, 2004, for details). Finally, on completion of a teaching sequence of 12 hours, the method of data-gathering for the main research phase was selected to be a system of post-interviews producing the core data, and pupils' learning diaries as secondary data. The main questions related to this study were presented in the post-interviews in a semi-structured format:

• "How do you know that you know?"

- "In your opinion, how does your teacher know that some things are as they are?" "How sure is s/he?"

- "How does a scientist know that something is as it is?" "How sure is s/he?"

The pupils were not directly asked about their opinions of the certainty of their own knowledge, since the pilot study had shown that it is very difficult to reflect on personal certainty. Instead, the pupils' responses in the interview data were interpreted to obtain an impression of each pupil's certainty of knowledge.

The interviews were transcribed and collected together with the ATLAS.ti programme. The qualitative analysis was based on the different conceptions and views expressed by the pupils. Phenomenographic analysis consisted of horizontal and hierarchic categorisations (cf. Uljens, 1989). All of the pupils' responses were horizontally classified into classes of conception, and then the classes were hierarchically combined into so called "meaning" categories, concerning their views of their own knowledge and the nature and certainty of teachers' and scientists' knowledge.

\section{RESULTS}

The two proposed components (justification and certainty) which were attached to the first research question, revealed a lot about the pupils' epistemological thinking; as a matter of fact, the third component - sources of knowledge - quite clearly emerged from the analysed data. Hofer (2000) states that the source of knowledge and the justification of knowledge belong to the same cluster. In the same cluster, together with certainty of knowledge, there should also be a fourth dimension - simplicity of knowledge (Hofer, 2000), but it was not recognised in the data. However, all the three components are in accordance with the epistemic views of the $7^{\text {th }}$-graders in this study. In the following, firstly the pupils' epistemic views are discussed in the light of epistemological resources and secondly, related to the levels of epistemological beliefs. 


\section{Pupils' epistemic views as epistemological resources}

The pupils' epistemic views which have emerged from the data are here analysed according to the categories of epistemological resources suggested by Hammer \& Elby (2002); many of them can be interpreted as being the same as suggested in their model, but also some new classes of epistemological sources, forms, and activities were discovered. The findings are presented in Table 3, which can be compared to the original model (Table 2).

Table 3. The epistemological resources with examples emerged in the study

\begin{tabular}{|c|c|}
\hline Categories & Epistemological resources with examples \\
\hline $\begin{array}{l}\text { Understanding } \\
\text { the nature of } \\
\text { knowledge }\end{array}$ & $\begin{array}{l}\text { Knowledge as propagated stuff } \\
\text { "teacher teaches as she has been taught" } \\
\text { Knowledge as free creation } \\
\text { invention } \\
\text { Knowledge as fabricated stuff } \\
\text { "can be concluded on the basis of other knowledge" } \\
\text { Knowledge as direct perception } \\
\text { "seeing it" } \\
\text { Knowledge as inherent } \\
\text { intuition; "feeling of knowing" } \\
\text { Authoritative sources* } \\
\text { teacher, textbook }\end{array}$ \\
\hline $\begin{array}{l}\text { Understanding } \\
\text { epistemic } \\
\text { activities }\end{array}$ & $\begin{array}{l}\text { Accumulation } \\
\text { learning } \\
\text { Formation } \\
\text { modelling; concluding; guessing } \\
\text { Checking } \\
\text { trying; testing; proving, comparing } \\
\text { Application } \\
\text { be able to explain; be able to remember }\end{array}$ \\
\hline $\begin{array}{l}\text { Understanding } \\
\text { epistemic } \\
\text { forms }\end{array}$ & $\begin{array}{l}\text { Stories } \\
\text { "things taught" } \\
\text { Rules } \\
\text { equations } \\
\text { Facts } \\
\text { proofs } \\
\text { Models* } \\
\text { atom model }\end{array}$ \\
\hline $\begin{array}{l}\text { Understanding } \\
\text { epistemic } \\
\text { stances }\end{array}$ & $\begin{array}{l}\text { Belief / disbelief } \\
\text { "I believe things that I cannot see"," I only believe what I see" } \\
\text { Doubting } \\
\text { "nothing is sure - there are always doubts" } \\
\text { Understanding / puzzlement } \\
\text { "one understands on her own way" } \\
\text { Acceptance } \\
\text { "if the others have come to the same conclusive result" }\end{array}$ \\
\hline
\end{tabular}

* Authoritative sources and models are new epistemic resources which have emerged in this study 
A considerable number of pupils described different sources of their own knowledge. These types of sources refer to knowledge as direct perception, propagated stuff or fabricated stuff (see the examples in Table 3). Many pupils referred to intuition, they could not specify the justification of their knowledge or they just had a "feeling of knowing" (cf. Koriat, 2000), which refers to knowledge as being inherent. Also "inventions" were mentioned and they are interpreted to represent knowledge as free creation.

Some of the pupils said that they knew something, if they were able to answer when asked about it, or if they could remember something; these samples refer to formation as an epistemological activity. Only two answers dealt with the evidence, and few pupils referred to rational thinking; proving and concluding could also be understood as epistemological activities.

In the pilot study, in which the interview themes were tested the certainty of the pupils' owns knowledge had seemed to be a difficult question for them, so this was not directly asked for in the main study. However, from their answers to other questions (which dealt with the content knowledge) some implicit information was received about individual pupils' views of the certainty of their knowledge. Their answers revealed considerable uncertainty. This might or might not be a sign of a relatively sound attitude towards knowledge. Some of the informants said that they "guessed", which also could be classified as an epistemological activity.

After pondering on their own knowledge, the pupils were asked about their teacher's knowledge and how certain she was. Some certainty of the teacher's knowledge was the first impression gained when analysing the responses. The pupils described the source of their teacher's knowledge as learning, studying, experience (all referring mainly to "fabricated stuff"), communication, and education (examples of "propagation"). Justification of the teacher's knowledge was based on learning by heart, age or proof: only a few interviewees referred to the evidence. "Remembering" could be classified as an epistemological activity as well as proving.

The certainty of the teacher's knowledge is described as being either sure or unsure. Many pupils referred to the teacher's position: "she must be sure because she teaches them". Some pupils considered the teacher's knowledge to be very sure. A teacher's position with the conceptions of certainty refers to teachers' "epistemic authority" that might have some connections to knowledge as propagated stuff. Authoritative sources, e.g. teachers, textbooks, etc. (cf. Reif \& Larkin, 1991) are suggested to be added to resources for understanding the nature and sources of knowledge in the model of Hammer \& Elby (2002).

The interviewees were also asked how a scientist knows a particular thing and how certain he/ she can generally be about it. The Finnish language uses 'tiedemies' - the concept representing 'scientist' which literally means 'scienceman'. In order to avoid the male bias, the word for 'researcher' was used instead of 'scienceman'. It is, however, quite obvious that the notion of "researcher" underlines the pupils' responses to 'researching' when asked something about 'a researcher's' knowledge. In dealing with the scientist's knowledge, source and justification were rather mixed in the pupils' answers. According to the pupils' views, the justifications for a scientist's knowledge include intuition and rational inference - concluding as an epistemological activity, or the use of models. "Modelling" could here be interpreted as one of epistemological activities; it could be seen like "playing a game" (cf. Hestenes, 1992). Other bases include proof, research and different sources - e.g. propagation. One of the pupils referred to equations, which can be classified as one of the examples in the epistemological forms.

In relation to certainty of knowledge, none of the pupils considered a scientist's knowledge to be certain, though some of them considered it to be reasonably reliable. Most pupils considered a scientist's knowledge to be fallible and unsure. Some responses describe the meaning of modelling: "If s/he makes a model of an atom, it is just an idea of an atom" (P29), "... s/he just tries to describe it to others by using a model" (P30). 


\section{Epistemic views in regard to the levels of epistemological beliefs}

When the pupils' epistemic views were examined in relation to the levels of epistemological beliefs (Table 1), the analysis revealed that there were views consistent with all the levels I-IV. The pupils' views on the lowest level considered, e.g., the certainty of knowledge and trust on others' knowledge (P33: "... if others have said that they know [it] for certain and also I know about [it] ... then I certainly [know]"), the necessity of perceptions for a judgement (P38: "Well ... usually, what I see I believe ... but if I can't see [it] and someone says [it], I don't necessarily believe [it]." - Int.: "Are there any things that you believe, though you have not seen them?" - P38: "No."), or the absolute position of authorities (Int.: "Are you absolutely sure about ..." - P21: “... it was said in that [text] book, and you have to believe the book, haven't you?"). The pupils' views, which were interpreted as belonging to the second level, acknowledged growing subjectivity and one's right to one's own opinions (Int.: "... if half of your class and the teacher agree on [something], could the others still be right?" - P27: "Yes, if it is an opinion at issue."); the authorities are not anymore omniscient (Int.: "Is your teacher always right?” - P25: “... maybe she isn't always right." - Int.: "Why?” - P25: "In principle, nobody can always be right..."). In the views classified into the third level the objectivity and certainty of knowledge are dissipating (P33: "Well, one cannot... [scientific knowledge] cannot be absolutely certain..., if researchers have noticed some atom, they cannot be absolutely sure of its kind... they can only estimate it."). On the highest level, there were some views in which the pupils evaluated authorities' knowledge in quite a mature way (Int: “... when can a researcher be wrong?" - P25: "If he has not scrutinised [a thing]... and if another [researcher] has and knows it [then] well.”; P35: “... a teacher's knowledge is not always certain.” - Int.: "Could it sometimes even be a pupil who confirms [that thing]?" - P35: "Yes, it can... because if the pupil has studied it more and knows about it... has [for instance] read a lot about it... or can prove it...").

Table 4. Exemplary interpretations of a pupil's (P29) responses according to the epistemological levels

\begin{tabular}{|l|l|l|}
\hline Excerpts from pupil H's post-interview & Interpretation & Level \\
\hline $\begin{array}{l}\text { Int.: How do you generally know that you know a thing? } \\
\text { P29: I've concluded it or then I've heard it from } \\
\text { somewhere... } \\
\text { Int.: Where does the certainty that you know it come from? }\end{array}$ & multiple sources \\
P29: It's proved or ... if I've seen it myself, then I believe. & & (II) \\
\hline $\begin{array}{l}\text { Int.: How does your physics teacher know that a certain } \\
\text { thing is as it is? }\end{array}$ & & \\
$\begin{array}{l}\text { P29: From the physics textbook or ... 'cause she is older } \\
\text { than us and so she has more wisdom than us in these } \\
\text { things... that amount of knowledge... }\end{array}$ & $\begin{array}{l}\text { objective knowledge } \\
\text { absolute authorities }\end{array}$ & (I) \\
\hline $\begin{array}{l}\text { Int.: How surely does your teacher know? } \\
\text { 29. Nobody knows very surely... }\end{array}$ & (II) \\
\hline $\begin{array}{l}\text { Int.: How does... a scientist know a certain thing is as it is? } \\
\text { 29: He/she can perceive it with some model... or... he can } \\
\text { try that thing himself... }\end{array}$ & $\begin{array}{l}\text { personal meaning making, } \\
\text { experimentation }\end{array}$ & (III) \\
\hline $\begin{array}{l}\text { Int.: Is the scientist sure of the model being right? } \\
\text { P29: ... a model is only an assumption, what [an atom] } \\
\text { could be... } \\
\text { Int.: So he/she cannot be absolutely sure? - H: No, he } \\
\text { can't... }\end{array}$ & critical evaluation of authorities & \\
\hline $\begin{array}{l}\text { Int.: Is it necessarily the teacher who decides [in a } \\
\text { controversial matter in class] who is right? } \\
\text { P29: Eh... one of the pupils could look it up in the textbook } \\
\text { or read from Internet if it is right... it is not necessarily the } \\
\text { teacher }\end{array}$ & $\begin{array}{l}\text { multiple sources } \\
\text { the teacher is not the only } \\
\text { authority }\end{array}$ & (IV) \\
\hline
\end{tabular}


It is not surprising that the pupils' epistemic views exist on all the epistemological levels in the whole data, but it is remarkable that even an individual pupil's views could be interpreted as belonging to several different levels. For instance, one of the pupils (P29) was interpreted as having beliefs that could be classified into all the levels I-IV in the model (see Table 4).

The reason, why the pupils' epistemic views included different levels of epistemological beliefs, was not in the focus in this study. Anyhow, it might stem out of the following questions: when does the process of epistemological understanding actually begin, and can the stances of the models of epistemological development be applied to particular individuals (cf. Hofer \& Pintrich, 1997)? Developmental research has mainly been carried out among adults or in late adolescence, and there is little evidence of younger people's abilities concerning epistemological beliefs. For instance, Boyes and Chandler (1992), using a four-stage model based on the former developmentally biased studies, found all the stages represented among the high school students in their study; they give as a plausible explanation that such development might be recursive in its nature. Also Muis, Bendixen and Haerle (2006) concur the idea that epistemological development is spiral-like rather than linear; i.e. there might be transitions toward lower stages when students move to another educational level. Most of the developmentally biased studies have also been quantitative with by nature, and as in this study, qualitative analysis could reveal different findings between individuals.

\section{Discussion AND CONCLUSIONS}

Two aspects of theoretical frameworks were applied in this study. First, two components of the epistemological theories suggested by Hofer and Pintrich (1997) were chosen to be the main items in pupils' thinking: the justification of knowledge and the certainty of knowledge. The second point of interest was whether Hammer \& Elby's (2002) model of epistemological resources would have any connections with the findings.

The main result seems to be that the developmental theories of personal epistemological beliefs are not the best for explaining young pupils' epistemic views. Amongst the 18 pupils involved in the study, both general and individual conceptions existed belonging to all four of the levels derived from earlier theoretical models (cf. Table 4). It can thus be claimed that theoretical models of development, which tend to assume that epistemological beliefs are general and coherent, in fact underestimate $7^{\text {th }}$-graders' epistemic views. In contrast, when such epistemological beliefs are approached in greater detail and their context taken into account, they can be seen to be structures that consist of epistemic primitives (cf. Hammer \& Elby, 2002), and thus offer the possibility of a promising and more pedagogically applicable approach (see, e.g. Louca, Elby, Hammer \& Kagey, 2004).

The pupils considered their teacher's knowledge to be quite certain and at the same time they seemed to have fairly sound views concerning scientists' knowledge. This result is quite remarkable: the teacher seems to be regarded as the origin of justified knowledge, but critical attitudes towards scientific knowledge nevertheless exist. This entails a challenge for school teaching: the teacher seems to be "a treasurer of knowledge". It refers to the transmission model of teaching, where the nature of science for students is seen as a fixed body of facts primarily accessed through authoritative sources, e.g., teacher (Newton, Driver \& Osborne, 1999). Since pupils trust the teacher of the textbook, consequently it may be hard to teach pupils to be critical.

A pleasing amount of resources for understanding the various aspects of epistemological items (Hammer \& Elby's model) were discovered among the findings, and new ones emerged that could be added to the model (cf. Table 3): authoritative sources - resources for understanding the nature and sources of knowledge, and modelling - resources for understanding epistemological activities. There were also some epistemic views that exemplify some sub-classes in the model: e.g., concluding and guessing - describing the resources related to the formation of knowledge and equations (like rules) - the resources for understanding epistemological forms. 
Pupils' epistemic views make sense in themselves. They should be considered as starting points for epistemological discussions in science classrooms instead of treating them as naïve or insignificant. Teachers should be aware of their pupils' underlying resources, and naturally, of their own "hidden resources" (cf. Louca et al. 2004). The curricula, textbooks, and standards for science education should also reflect epistemological understanding. One previous study conducted in Finland (Sormunen 1999) has for instance revealed that teachers and student teachers have quite a poor conception of the epistemological background of physics. It would be valuable for teachers to know some ideas of the philosophical basis of science (cf. Abd-El-Khalick \& Lederman, 2000) and also the basis of pupils' epistemological ideas. It would also be crucial for teachers to recognise their own epistemic views. As a result the teachers' performance would probably be much more efficient when teaching epistemological ideas related to science and even science per se.

\section{REFERENCES}

Abd-El-Khalick, F. \& Lederman, N. G. (2000). Improving science teachers' conceptions of nature of science: A critical review of the literature. International Journal of Science Education, 22, 665-701.

Baxter Magolda, M. B. (1992). Knowing and Reasoning in College: Gender-Related Patterns in Students' Intellectual Development. San Francisco, CA: Jossey Bass.

Belenky, M. F., Clinchy, B. M., Goldberger, N. R. \& Tarule, J. M. (1986). Women's ways of knowing: the development of self, voice and mind. New York, NY: Basic Books.

Blanco, R. \& Niaz, M. (1997). Epistemological beliefs of students and teachers about the Nature of Science: From 'Baconian inductive ascent' to the 'irrelevance' of scientific laws. Instructional Science, 25, 203-231.

Boyes, M. C. \& Chandler, M. (1992). Cognitive development, epistemic doubt, and identity formation in adolescence. Journal of Youth and Adolescence, 21, 277-303.

Carlsson, B. (1999). Ecological Understanding - A Space of Variation. Luleå University of Technology.

Collins, A. \& Ferguson, W. (1993). Epistemic forms and epistemic games: Structures and strategies to guide inquiry. Educational Psychologist, 28, 25-42.

Donnelly, J. (1999). Interpreting Differences: The educational aims of teachers of science and history, and their implications. Journal of Curriculum Studies, 31, 17-41.

Hammer, D. \& Elby, A. (2002). On the Form of a Personal Epistemology. In B. K. Hofer and P. R. Pintrich (Eds.), Personal Epistemology: The Psychology of Beliefs about Knowledge and Knowing (pp. 169-190). Mahwah, NJ: Erlbaum.

Hestenes, D. (1992). Modeling games in the Newtonian World. American Journal of Physics, 60, 732-748.

Hitchcock, G. \& Hughes, D. (1995). Research and the Teacher. A Qualitative Introduction to School-Based Research. London: Routledge.

Hofer, B. K. (2000). Dimensionality and disciplinary differences in personal epistemology. Contemporary Educational Psychology, 25, 378-405.

Hofer, B. K. \& Pintrich, P. R. (1997). The development of epistemological theories: Beliefs about knowledge and knowing and their relation to Learning. Review of Educational Research, 67, 88-140.

Hogan, K. (2000). Exploring a Process view of students' knowledge about the Nature of Science. Science Education, 84, 51-70.

Kelly, G. J., Chen C. \& Crawford T. (1998). Methodological considerations for studying science-inthe-making in educational settings. Research in Science Education, 28, 23-49.

King, P. M., Kitchener, K. S., Davison, M. L., Parker, C. A. \& Wood, P. K. (1983). The justification of beliefs in young adults: a longitudinal study. Human Development, 26, 106-116.

Koriat, A. (2000). The feeling of knowing: some metatheoretical implications for consciousness and control. Consciousness and Cognition, 9, 149-171. 
Kuhn, D. (1991). The Skills of Argument. New York: Cambridge University Press.

Lederman, N. G. (1992). Students' and teachers' conceptions of the Nature of Science: A review of the research. Journal of Research in Science Teaching, 29, 331-359.

Louca, L., Elby, A., Hammer, D. \& Kagey, T. (2004). Epistemological resources: applying a new epistemological framework to science instruction. Educational Psychologist, 39, 57-68.

McComas, W. F. \& Olson, J. K. (1998). The nature of science in international science education standards documents. In W. F. McComas (Eds.), The Nature of Science in Science Education. Rationales and Strategies (pp. 41-52). Dordrecht: Kluwer.

Muis, K. R., Bendixen, L. D. \& Haerle, F. C. (2006). Domain-generality and domain-specificity in personal epistemology research: philosophical and empirical reflections in the development of a theoretical framework. Educational Psychology Review, 18, 3-56.

Newton, P., Driver, R. \& Osborne, J. (1999). The Place of Argumentation in the Pedagogy of School Science. International Journal of Science Education, 21, 553-576.

Perry, W. G. (1970). Forms of Intellectual and Ethical Development in the College Years: A Scheme. New York: Holt, Rinehart and Winston.

Reif, F. \& Larkin, J. H. (1991). Cognition in scientific and everyday domains: Comparison and learning implications. Journal of Research in Science Teaching, 28 733-760.

Roth, W. \& Roychoudhury, A. (1994). Physics students' epistemologies and views about knowing and learning. Journal of Research in Science Teaching, 31, 5-30.'

Saari, H. \& Viiri, J. (2003). A research-based teaching sequence for teaching the concept of modelling to seventh-grade students. International Journal of Science Education, 25, 1333-1352.

Smith C. L., Maclin D., Houghton, C. \& Hennessey, M. G. (2000). Sixth-grade students' epistemologies of science: The impact of schools science experiences on epistemological development. Cognition and Instruction, 18, 349-422.

Sormunen, K. 1999. Nature of physics - teachers' views. In M. Bandiera, S. Caravita, E. Torracca \& M. Vicentini (Eds.), Research in Science Education in Europe (pp. 235-243). Dordrecht: Kluwer Academic Publishers.

Sormunen, K. (2004). Seitsemäsluokkalaisten episteemiset näkemykset luonnontieteiden opiskelun yhteydessä. [Seventh-graders' epistemic views related to science lessons]. (Publications in Education no. 95). University of Joensuu.

Säljö, R. 1988. Learning in educational settings. In P. Ramsden (Ed.), Improving Learning. New Perspectives (pp. 32 - 48). London, UK: Kogan Page.

Uljens, M. 1989. Fenomenografi - forskning om uppfattningar. Lund: Studentlitteratur.

Yin, R. K. (1994). Case Study Research. Design and Methods. Thousand Oaks, CA: Sage. 